\author{
Karol Jasiński \\ Uniwersytet Warmińsko-Mazurski w Olsztynie \\ ORCID 0000-0002-7695-499X
}

\title{
The Internal Secularisation of Religion
}

\begin{abstract}
The author of the article deals with the subject of internal secularisation of religion, which can occur on many different levels (privatisation of religious life, changing the universe of meaning, adapting religion to contemporary culture, dying of sensitivity to the "sacrum," primacy of politics over religion). Three important manifestations of internal secularisation, which we are currently dealing with, have been analysed. The first one is to secularise the consciousness of believers. The second - excessive institutionalisation and bureaucratisation of religion. Whereas the third is the dominance of secular (auxiliary) functions rather than typically religious (essential) ones.
\end{abstract}

Keywords: religion, secularisation, consciousness, institutionalisation, religious functions

\section{Introduction}

The notion of progressing secularisation of societies, of the religion losing its significance and impact on various aspects of the personal and social life has been common from the time of Emil Durkheim, Max Weber, Gabriel Le Bras and Peter Berger until the early 1990s. It was stressed that it was a typical Western European (Christian) phenomenon. Secularisation as a social process in culture was distinguished from secularism as an ideology which was a form of hostility towards religion and striving to eliminate it. However, these theories were corrected in the 1990s and desecularisation emerged, described as the rebirth of religion. ${ }^{1}$ Socio-religious life seems to take place in a kind of tension between secularisation and desecularisation.

1 Cf. P.L. Berger, "The Desecularization," 1-18. 
Secularisation and desecularisation take place not only within society but also in religion itself. The German sociologist Thomas Luckmann sometimes uses the term "internal secularisation."2 It is used to describe the privatisation of religious life, changes in the universe of meaning, the adaptation of religion to culture and the internal experience of many religious communities where sensitivity to the sacrum is dying out. ${ }^{3}$ According to the Italian Church historian Roberto Pertici, internal secularisation manifests itself in the preeminence of politics over spirituality in religion. ${ }^{4}$

What are the other manifestations of internal secularisation of religion? Three principal ones should be mentioned. First, there is the the secularisation of the faithful's consciousness. Second, there is excessive institutionalisation and bureaucratisation of religion. Third, there is the performing mainly of lay (e.g., cultural, social, charity) rather than typically religious functions. Therefore, let us look at each of these manifestations of internal secularisation which can be found in every religion. ${ }^{5}$

\section{The secularisation of the faithful's consciousness}

The American sociologist Peter Berger noted that secularisation is objective and subjective in nature. In the former, it involves the disappearance of religious aspects in arts, philosophy, literature, and science. In the latter - the secularisation of consciousness, i.e., the human perception of reality while leaving out the religious interpretation. Man has a wide range of methods of understanding

2 Cf. T. Luckmann, Niewidzialna religia, 161.

3 Cf. C. Korzec, "Kościół w doświadczeniu," 41-45.

4 Cf. R. Pertici, "Primacy of the Spiritual."

5 The author is aware of the fact that the issue of secularisation presented in the article is discussed mainly from a philosophical and sociological perspective. Nevertheless, can also be valuable in theological reflection on the phenomenon of secularisation. In addition, theological analyses sometimes rely on conceptual apparatus and certain intuitions derived from other disciplines, including philosophy and sociology. Hence, the decision to publish this article in a theological journal. 
reality, none of which can be regarded as the only one valid. ${ }^{6}$ The Guinean theologian Robert Sarah emphasises instead, that succumbing to the influence of materialism and consumerism, a modern believer adopts a secular way of thinking and perceiving reality that lacks reference to the given revelation. ${ }^{7}$

In modern times, therefore, we are witnessing an important phenomenon of secularisation of consciousness, which is also referred to as privatisation, subjectivisation, patchwork religiosity, cocktail religiosity or dispersed religiosity. The meaning of religion is therefore changing both at the public level and at the level of individual consciousness. The reason for this process is, on the one hand, cultural changes, which include, among others, the development of science. On the other hand, following the suggestion of the social philosopher Andrzej Szahaj, secularisation of consciousness may be related to the transition from theocentric to anthropocentric vision of the world in Western culture. ${ }^{8}$

It seems that secularisation of consciousness can manifest itself in several essential ways. First, secularisation can involve the elimination of the supernatural from religion and human thinking. It is done in three ways. Firstly, attempts are made at the interpretation of religion in the context of some philosophical currents (e.g., existentialism, logical empiricism). Secondly, the results of scientific research in which the thesis of the existence of the supernatural reality is shown to be baseless are accepted uncritically. Thirdly, there is a noticeable fascination with criticism of religious text whose authors stress only their mythical nature. This results in the secularisation of theology. ${ }^{9}$ Attempts are also made at reconciling theology with human knowledge. ${ }^{10}$ The reconciliation itself is not a negative phenomenon. It is even recommended because religious teaching should comply with standards of rationality and should not clash with findings of

6 Cf. P.L. Berger, "Sekularyzacja,” 98; P.L. Berger, Święty baldachim, 150, $159,173$.

Cf. R. Sarah, N. Diat, Wieczór się zbliża, 403-404.

Cf. A. Szahaj, "Wielość, względność," 17.

9 Cf. C. Korzec, "Kościół w doświadczeniu," 41-45; E.L. Mascall, Sekularyzacja chrześcijaństwa, 17, 34.

10 Cf. J. Mariański, "Sekularyzacja,” 185-200, 185-187. 
specific branches of science. However, one cannot deform or question religious teaching at all costs because of variable currents of thought.

However, one should bear in mind that - as the German philosopher and sociologist Max Weber pointed out - rationalisation of religion is a form of secularisation. In abandoning the primary forms of religion and giving up all its magical elements, one ends up questioning religion. ${ }^{11}$ Obviously, magical forms must be removed from religion. The process contributes to increasing the area of religious freedom, searching for transcendence, deepening of religiousness, and discovering the fuller truth of God, man, and the world. ${ }^{12}$ However, when done radically it can result in questioning religion. It should also be noted that there is a fundamental difference between magic and religion. In magic, man wants to gain power over deities and their powers, and in religion, he wants to surrender completely to God/ deity. Thus, the presence of the elements of magic in religions is not only a form of syncretism, but also a certain aberration of religion.

Secondly, man no longer lives according to the essence and mentality of faith. Thomas Aquinas stressed that faith helps man to know God better. It involves seeing and judging everything as if with God's eyes. It gives man a new vision of reality and a new mentality. ${ }^{13}$ Now people have lost a religious vision of reality and the perspective associated with it. The mentality of believers has been appropriated, "colonised" by currently dominant secular rationality. They do not understand themselves and they do not interpret the world in religious categories, but in secular categories (sometimes purely scientific) that are often alien to their religion.

According to Leon J. Suenens, man does not live in line with the logic of faith. He reduces it to religious practices, which are devoid of any content and have become an empty ritual. ${ }^{14}$ Therefore, it is a situation practiced by non-believers.

11 Cf. M. Weber, Racjonalność, władza, 124.

12 Cf. A. Napiórkowski, "Współczesny sekularyzm,” 11-36, 30, 34-35.

13 Cf. T. Dajczer, Rozważania o wierze, 23-24, 31.

14 Cf. L.J. Suenens, Nowe Zesłanie, 113-115, 119. 
Thirdly, secularisation of consciousness involves the privatisation of religion and removal of its symbols from the social tissue. ${ }^{15}$ Religion is regarded as an element of man's intimate sphere and man should not reveal his beliefs in interpersonal contacts. Privatisation is associated with their subjectivisation, i.e., transformation caused by individual attitudes and preferences. ${ }^{16}$ In consequence, religion becomes arbitrary, selective, and syncretic. ${ }^{17}$ Autonomy is its predominant feature, but it is also a manifestation of secularisation. ${ }^{18}$ However, one should bear in mind that religious beliefs are basically unchangeable, and only the social conditions of their understanding and expression change. ${ }^{19}$

Fourthly, religious content changes when people's preferences are taken into account. It is becoming difficult to maintain the unchanged religious truth because its content becomes an object of fashion. The religious sphere is infiltrated with dynamic consumer preferences, which result in a changing of the faith content. Such preferences usually reflect the needs of man's private sphere. Religion enjoys popularity, as long as it is appropriate for private life. Its moral and therapeutic functions are stressed..$^{20}$ Modification of religious content results in changes in the systems of beliefs. ${ }^{21}$

Fifthly, human outlook on life is secularised. Religion gives way to lay outlooks on life, associated with differentiation of social practices guided by their own axiology (e.g., profit in the economy, originality in art). The effect of technocratic and consumeristic outlooks on life is also noticeable. Pluralism of outlooks leads to mental and epistemic relativisation. Due to their multitude, none of them is regarded as absolutely true. ${ }^{22}$ In Taylor's language, it makes religion one of many outlook options. Given the pluralism, individuals can choose different religions, but they can also choose none and construct their own life

15 Cf. V. Possenti, Religia i życie publiczne, 6.

16 Cf. A. Szahaj, Liberalizm, wspólnotowość, 101-101; A. Szahaj, "Wielość, względność," 16-18.

17 Cf. A. Szahaj, Liberalizm, wspólnotowość, 77-78.

18 Cf. P. Mazanka, "Refleksje o filozoficznych," 55-83, 58-59.

19 Cf. T. Luckmann, Niewidzialna religia, 153, 161.

20 Cf. P.L. Berger, Święty baldachim, 193-197.

21 Cf. A. Kasperek, "Sekularyzacja," 308.

22 Cf. A. Szahaj, Liberalizm, wspólnotowość, 98-100. 
options. Being one of many options, religion ceases to be a matter of fate and becomes a matter of choice.

Moreover, Berger stresses that there is a link between pluralism and secularisation. Secularisation contributes to demonopolisation of religious traditions and, in consequence, it leads to pluralism. Pluralism in turn leads to a free market of religions on which they become consumer articles. ${ }^{23}$ Szahaj points out that the capitalist freemarket approach to religion leads to its commercialisation. ${ }^{24}$

It seems that secularisation of religious consciousness may be associated with the crisis of human rationality. In the past, human reason had two levels: wisdom and knowledge. Wisdom gave the man the ability to read the sense of reality and the knowledge - the ability to identify the appropriate measures to accomplish one's goals. This wisdom-oriented dimension of thinking is lost and instrumental reasoning is dominating. ${ }^{25}$ Therefore, there is an urgent need to abandon the rationality that is only instrumental and to return to the wisdom-oriented dimensions of human thinking.

The need to stimulate religious thinking in people, postulated by the Polish dialogist Józef Tischner, is another significant challenge. It involves reconciliation of the faith with reason and the reason with faith, opening to credible witnesses and referring man to transcendence. ${ }^{26}$ Religious thinking leads man not only to the discovery and acceptance of the truth, but also to the sense of his existence.

\section{Institutionalisation and bureaucratisation of religion}

Excessive institutionalisation and bureaucratisation are other important manifestations of religious internal secularisation. The consequence of these processes is, according to Sarah, the loss of its spiritual depth by religion and the assumption of administrative structures, which takes place at the cost of losing its communal, even

\footnotetext{
23 Cf. P.L. Berger, Święty baldachim, 182, 185-186, 200-202, 218.

${ }^{24}$ Cf. A. Szahaj, "Wielość, względność," 19-20.

25 Cf. R. Buttiglione, Etyka w kryzysie, 21-28.

${ }^{26}$ Cf. J. Tischner, Myślenie według wartości, 339, 342-348, 351, 358.
} 
family, character. ${ }^{27}$ While according to the German theologian Walter Kasper, excessive institutionalisation and bureaucratisation lead to the clouding of the Church spiritual profile and put it on one level with other lay organisations. Its credibility can be regained by dismantling excessive structures. ${ }^{28}$ It can also make its activities more effective.

What is an institution? It is an organisation - a team of cooperating individuals equipped with appropriate resources. ${ }^{29}$ It comprises people and their apparatus. ${ }^{30}$ Institutionalisation, which is an important method of regulating social life, is a process of transition from nonformalised to regulated ways of social activity.

Therefore, religion would be an institution as it comprises individuals in possession of proper resources that enable a relation with the Absolute. It is on this basis that certain activities are formalised that have their source in the internal experience of an individual or a group. Institutionalisation supports attempts at ordering, verifying, and controlling specific experience and practices.

The concept of bureaucracy is inseparable with that of administration. Administration is understood as denoting the management of some matters. It is characterised by three features: initiating organisational activities, solving specific problems, and acting through non-executive measures. Bureaucracy is characterised by the following features: division of the scope of authority, hierarchy of offices, modern organisation of administration, professional qualifications, and performing one's duties in accordance with general rules. ${ }^{31}$ Administration and bureaucracy are also inseparable elements of institutionalised religion. They can support its effective functioning. However, their excessive growth sometimes results in paralysis of religious life and in suppressing the spiritual element.

In Luckmann's opinion, religion is an institutionalised conglomerate of beliefs and behaviours and religion is equated with an institution (e.g., the Church). ${ }^{32}$ The Australian phenomenologist

27 Cf. R. Sarah, N. Diat, Wieczór się zbliża, 67, 80.

28 Cf. W. Kasper, Miłosierdzie, 190-191.

${ }^{29}$ Cf. T. Pszczołowski, Mała encyklopedia, 86.

30 Cf. J. Zieleniewski, Organizacja zespołów ludzkich, 84.

31 Cf. E. Sokalska, "Biurokracja jako metoda," 115-124, 115-118, 120-121.

32 Cf. T. Luckmann, Niewidzialna religia, 88-91. 
of religion Eris Sharpe mentions four aspects of religion: existential (trust), intellectual (a set of claims), ethical (actions) and institutional (institutions that maintain and transmit the forms of faith). ${ }^{33}$ According to Polish philosopher Jan Woleński, it is difficult to imagine religious communities without an intellectual base. ${ }^{34}$ Swiss intellectual Alain de Botton, emphasises additionally the positive nature of religious institutions that give a sense of identity and propose practices (rites) aimed at realizing the spiritual life. ${ }^{35}$

With respect to Christianity, the American intellectual George Weigel stresses that too much weight has been attached to the Church as an institution. It should be seen rather as an evangelical movement. Structures may be useful, but they should be ancillary to the Church as the movement. Therefore, the Church should be reconceived, not so much as an institution but as a dynamic evangelical movement, whose main mission is to preach the redemptive truth. ${ }^{36}$ Therefore, institutions are needed in a religion as it has not only a subjective, but also an objective dimension. Objectivisation, specification and verification of faith take place within the institution. ${ }^{37}$ However, they cannot obscure the main goal of a religion, which is to establish a relation between man and the Absolute and to inspire his spiritual development in a community.

Following Luckmann's train of thought, one should note that each religion undergoes structural transformations, institutional specialisation, and bureaucratisation. Specialisation is a social form of religion, which is characterised by standardisation of convictions in the form of the doctrine, division of roles, being organised and having sanctions to enforce unity. Therefore, religion adapts to the lay way of life and starts to implement goals that are foreign to it. In consequence, in Luckmann's opinion, a kind of degradation of religion takes place, with the ambivalence of its goals and loss of credibility. ${ }^{38}$

33 Cf. E. Sharpe, Understanding Religion, 95.

34 Cf. J. Woleński, Granice niewiary, 24.

35 Cf. A. de Botton, Religion for Atheists, 298.

36 Cf. G. Weigel, Czym jest katolicyzm?, 47-49, 52-53.

37 Cf. A. Napiórkowski, "Współczesny sekularyzm," 31.

38 Cf. T. Luckmann, Niewidzialna religia, 89, 102, 107, 137, 143, 150-151, 172. 
Bureaucratisation is another form of structural changes in religion. ${ }^{39}$ According to Berger, it is a manifestation of structural rationalisation. In its consequence, structures become similar to one another. Religious institutions are then not only administered in a bureaucratic manner, but they are also dominated by the logic of bureaucracy. It is manifested by maintaining relations with other institutions, with clientele, creating lobbies to influence the government and creating foundations. Bureaucracy demands appropriate personnel with certain mental skills and features to perform specific functions. Therefore, religious institutions select and train appropriate kinds of workers, often similar to bureaucratic personalities in other institutions. They are pragmatically oriented activists, not prone to reflection, with good interpersonal skills, who are dynamic and conservative. ${ }^{40}$

However, according to Weigel, the consequences of religious bureaucratisation are wrong. It results in an excessive increase in the number of officials, an increase in financial resources spent on administration and delaying decisions as a consequence of seeking expert opinions, an excessive number of councils which undermine authority and the existence of various interest groups which undermine decisions and avoid confrontations. Therefore, bureaucratisation results in a crisis of religion as an institution. ${ }^{41}$ According to the Polish theologian Michał Wojciechowski, bureaucratisation, including its religious dimension, causes such negative phenomena as high costs, restricting the freedom of decisions, lack of officials' responsibility, and a complicated and impersonal bureaucratic system. ${ }^{42}$ The latter defect of bureaucracy is particularly harmful to religion, in which personal preferences play an important role.

Further, excessive institutionalisation and bureaucratisation lead to secularisation, which manifests itself as people abandoning the institutional forms of religiousness and the community reducing the importance of religious life. ${ }^{43}$ Therefore, empty churches are

${ }^{39}$ Cf. K. Dobbelaere, Sekularyzacja, 33-39, 43-46, 49-66.

${ }^{40}$ Cf. P.L. Berger, Święty baldachim, 187-189.

${ }^{41}$ Cf. G. Weigel, Czym jest katolicyzm?, 49-50; G. Weigel, Odwaga bycia katolikiem, 84-86, 185-186.

${ }^{42}$ Cf. M. Wojciechowski, Teolog o ekonomii, 124-125.

${ }^{43}$ Cf. A. Napiórkowski, "Współczesny sekularyzm," 12, 30. 
not necessarily a sign of the twilight of religiousness in general, but only a symptom of the crisis of institutionalised religion. Various forms of religiousness and extra-ecclesial spirituality can become more visible. ${ }^{44}$

When man distances himself from institutionalised religion it is called spirituality. It is a form of secularisation. When it comes to spirituality, it does not involve diminishing of individual religiousness, piety or religious practices, but only a loss of control by religious authorities over individuals' beliefs and practices. ${ }^{45}$ Spirituality in its extreme forms has no associations with the Transcendence, but it is associated with one's "self," inner experience, seeking sacrum without religious institutions as intermediaries, the need for personal development, self-searching and exploration. ${ }^{46}$ It should be emphasised that spirituality is understood in this case in the sense given to this concept at the turn of the 20th and 21st centuries. Since that time, the opposition "spirituality-religion" and the talk about the so-called "new spirituality" have become more and more popular. The main feature of this kind of spirituality is the lack of ties with institutional religion and its being based on individual human needs. Meanwhile, spirituality and religion should not be placed in opposition to each other. Rather, it should be said that secularisation causes the separation of religion from spirituality and the reduction of the former to superficial religiosity.

There is, therefore, a transition from ecclesial to privatised nonecclesial religiousness. Notably, the religiousness of traditional societies used to be ecclesial, institutional, organised, and specialised. In contrast, modern religiousness is non-ecclesial and independent of the values and norms established and propagated by Churches. People think of themselves as faithful, but they develop their religious lives outside institutional forms of religion. They want to define their attitude to religion themselves. Therefore, in spirituality there is a transition from institutionalisation to deinstitutionalisation,

44 Cf. J. Mariański, Sekularyzacja, desekularyzacja, 93-94, 105; A. Napiórkowski, "Współczesny sekularyzm," 32.

45 Cf. K. Dobbelaere, Sekularyzacja, 30.

46 Cf. J. Mariański, Sekularyzacja, desekularyzacja, 148, 151, 170. 
from heteronomy to autonomy, from great to medium and small Transcendence (e.g., ideology, human “self”). ${ }^{47}$

According to Luckmann, institutional forms of religion are replaced by its privatised version. Based on his own preferences, man chooses a certain set of ideas, which give his life meaning and build his outlook on life. He does not feel the need for religious institutions to act as intermediaries in his spiritual life. His religiousness is founded on an emotional experience, which makes it unstable. ${ }^{48}$

Considering the processes of institutionalisation and bureaucratisation in religion, one should arrive at the conclusion that religious structures should adapt to modern times, but they should also meet man's spiritual needs. One cannot attach a greater weight to organisation and institution in religion than to opening oneself to God and man. If one succumbs to the temptation of institutionalisation and bureaucratisation, it will become infiltrated by corporate logic ${ }^{49}$ and religion will lose its character.

\section{Secularisation and functions of religion}

Religion performing mainly lay (e.g., cultural, social, charity) rather than typical religious (spiritual) functions is the third symptom of its internal secularisation. It seems that the proper functions of religion arise from its very nature.

So, what is religion? Religion is a kind of relationship between man and the Absolute understood in various ways. It would be manifested by individual spiritual experience, the doctrine, cult, and community. Therefore, religion has specific functions to play in the world. Some suggestions are provided by the authors who examine the etymology of the word "religion." Cicero derived the term from the Latin relegere (read again), Lactantus - from religare (bind), and Augustine of Hippo - from reeligere (choose something again)..$^{50}$

47 Cf. J. Mariański, Sekularyzacja i desekularyzacja, 82-84, 87-104, 113.

48 Cf. Luckmann, Niewidzialna religia ..., 161, 165, 169-171, 175-177, 200-202.

49 Cf. M. Gierycz, "O liberalnych i konserwatywnych «pokusach» Kościoła Katolickiego," 133-134.

50 Cf. Z.J. Zdybicka, Człowiek i religia, 280-281, 359-368. 
Therefore, the main function of religion should be to help man to read again and interpret his life in the transcendent perspective, to establish a relationship with the Absolute and to choose God and, in consequence, a specific lifestyle.

Other functions of religion have also been mentioned. They include: the humanisation of the world and guarding the personal dignity of man, enabling man to embrace the infinite, integration of man with respect to the supernatural reality, securing socially recognised values, achieving salvation, imparting sense and divine dimension to passing life, inclusion in the deepest structure of the reality, removing existential contradictions, struggling with the ultimate life issues with beliefs and practices, integration of the community around beliefs and practices. ${ }^{51}$

The German sociologist Niklas Luhmann regards religion as a subsystem of the society and mentions its main spiritual function and various ancillary functions. The spiritual function involves imparting a sense to various situations and circumstances by reference to their sacrum and providing specific redemptive goods. Ancillary functions can include economic, educational, and political functions. Ineffectiveness, a low impact on people and problems in performing the spiritual function make religion sometimes more oriented towards ancillary functions. The spiritual function is thereby limited, but it is still a determinant of the religious identity. The pre-eminent function of religion changes from main to ancillary. Therefore, the weakness of the spiritual function is compensated for by social activity, which must be adapted to people's expectations. However, in his opinion, a transition from the spiritual to the ancillary functions is a manifestation of secularisation. ${ }^{52}$

In contrast, the Polish sociologist Janusz Mariański points out that religion fulfilled not only its strictly religious, but also social functions, including substitutive ones, in a totalitarian system. They should be performed by public institutions in a democratic system. He points out that abandoning the performance of substitutive functions is sometimes regarded as a manifestation of the downfall of religious

51 Cf. Ibid., 293-295.

52 Cf. N. Luhmann, Funkcja religii, 22-28, 35-40, 54, 219-233, 252-261. 
authority. However, according to Mariański, it is beneficial for both religion and society. Religion must care about preserving its identity rather than become an educational institution, an economic partner or a political rival. Above all, it must be a community of salvation for all people and a force influencing the shape of society's moral nature. Therefore, religion should perform its specific redemptive functions in society. They include preaching God's word, the liturgical and worship function and the ancillary function. Other functions, especially those of a socio-cultural nature, are only supplemental to those former ones. However, it does not mean that they should be given up. Only appropriate proportions should be maintained in performing them to avoid losing their character. ${ }^{53}$

Reducing religion to ethics is a danger that is frequent nowadays. An attempt is made at determining religious identity by referring to a set of specific values. A Christian is then defined as a good, just, merciful person, with a social sense. However, Christianity is not a set of rules and values, but a personal relation with Jesus. ${ }^{54}$ It is the same for every religion. Especially that the values that are regarded as religious are generally universal human values.

In consequence of reducing religion to ethics, its moral function, especially serving the poor, is absolutised. This especially happens in Protestant churches. ${ }^{55}$ However, there is a specific tension between religion and its moral content. It manifests itself in the lack of coherence between the theory and practice, moral teaching, and conduct. ${ }^{56}$ Therefore, one cannot equate religion and morality and reduce it to its moral function.

The politicisation of religion, which is a sign of its weakness and crisis, is another example of domination of the ancillary functions of religion over its primary one. It manifests itself in strong ties between religion and authority and attempts by authorities to use religion and vice versa.

\footnotetext{
53 Cf. J. Mariański, Kościół katolicki, 22-23, 45-46, 117, 146-147, 161.

54 Cf. L.J. Suenens, Nowe Zesłanie, 132.

55 Cf. A. Napiórkowski, "Współczesny sekularyzm," 30.

56 Cf. A. Szahaj, Liberalizm, wspólnotowość, 103-104.
} 
As Szahaj points out, the closer the links between religion and authorities, the more rapid its secularisation. ${ }^{57}$ Strong links between religion and politics also result in ideologisation of the former, due to which it loses its proper character.

Therefore, one must accept that religion is not limited to performing its redemptive functions, but it also plays ancillary functions (e.g., educational, cultural, social, charity, political). Therefore, it cannot be situated on the margin of social issues. ${ }^{58}$ Ancillary functions of religion, performed for specific individuals, groups or the whole society, should be regarded as "lay" rather than typically "religious," according to the traditional terminology used by religious institutions themselves. ${ }^{59}$ Therefore, they should be performed with moderation for the sake of maintaining the religious identity and pursuing a strictly spiritual mission.

\section{Conclusion}

These considerations dealt with three important manifestations of internal secularisation of religion observed nowadays. First, is the secularisation of the faithful's consciousness. Second, there is excessive institutionalisation and bureaucratisation of religion. Third, there is the performance of mainly lay (ancillary) rather than typical religious (main) functions.

It seems that the faithful should not abandon the beliefs and the vision of the world offered to them by their religion. However, it does not mean that they would have to influence their consciousness uncritically. Therefore, the faithful should eliminate all superstitions from such beliefs and reconcile them with the findings of specific sciences. Likewise, one should not give up on any form of religion institutionalisation, whose aim is to bring order to their spiritual life, especially in the community dimension. Some structures are needed because they can provide a framework for spiritual life. Owing to them, man not only rejects the temptation of arbitrariness and spiritual

57 Cf. A. Szahaj, Liberalizm, wspólnotowość,104.

58 Cf. J. Woleński, Granice niewiary, 27.

59 Cf. T. Luckmann, Niewidzialna religia, 68-71. 
narcissism, but he can also make his spiritual experience objective and maintain a relationship with the Absolute and satisfy the need for belonging and identity. Regarding the functions performed by religion, the main emphasis should be placed on the main, spiritual function, without giving up on the secondary ancillary functions. These can be an extension of the first function (e.g., education) or an integral element of religious activity (e.g., medical and social aid). The proper distribution of emphasis and maintaining the right proportions are both particularly important in this case.

Internal secularisation of religion may be a negative phenomenon as it leads to a crisis and degradation of religion, but secularisation in a broader sense may bring positive effects to religion. It is because it plays a critical and cleansing role. It can help faith to develop and can open a way to changing old patterns. Secularisation can also contribute to a rediscovery of the true nature of religion, owing to which its representatives will start to conduct their spiritual mission better.

\title{
Wewnętrzna sekularyzacja religii
}

\begin{abstract}
Abstrakt: Autor artykułu podejmuje temat wewnętrznej sekularyzacji religii, która może zachodzić na wielu różnych płaszczyznach (prywatyzacja życia religijnego, zmiana uniwersum znaczeń, dostosowanie religii do współczesnej kultury, zamieranie wrażliwości na "sacrum”, prymat polityki nad religią). Analizie zostały poddane trzy ważne przejawy wewnętrznej sekularyzacji, z którą mamy obecnie do czynienia w religii. Pierwszym z nich jest sekularyzacja świadomości wierzących. Drugim - nadmierna instytucjonalizacja i biurokratyzacja religii. Trzecim natomiast jest dominacja funkcji świeckich (pomocniczych) nad typowo religijnymi (istotnymi).
\end{abstract}

Słowa kluczowe: religia, sekularyzacja, świadomość, instytucjonalizacja, funkcje religijne

\section{Bibliography}

Berger, P.L., "The Desecularization of the World. A Global Overview," in: P.L. Berger (ed.), The Desecularization of the World. Resurgent Religion and World Politics, Washington D.C. 1999, 1-18.

Berger, P.L., "Sekularyzacja a problem wiarygodności religii," W. Kurdziel (transl.), in: F. Adamski (ed.), Ateizm oraz irreligia i sekularyzacja, Kraków 2011, 96-112. 
Berger, P.L., Święty baldachim. Elementy socjologicznej teorii religii, W. Kurdziel (transl.), Kraków 1997.

Botton, A. de, Religion for Atheists. A Non-believer's Guide to Uses of Religion, London 2012.

Buttiglione, R., Etyka w kryzysie, J. Merecki (transl.), Lublin 1994.

Dajczer, T., Rozważania o wierze. Z zagadnień teologii duchowości, Częstochowa 1992.

Gierycz, M., "O liberalnych i konserwatywnych «pokusach» Kościoła Katolickiego," in: S. Dudra, R. Michalak, Ł. Młyńczyk (eds.), Polityczne uwarunkowania religii - religijne uwarunkowania polityki, Zielona Góra 2017, 119-136.

Dobbelaere, K., Sekularyzacja. Trzy poziomy analizy, R. Babińska (transl.), Kraków 2008.

Kasper, W., Miłosierdzie. Klucz do chrześcijańskiego życia, R. Zajączkowski (transl.), Poznań 2014.

Kasperek, A., "Sekularyzacja nie chce spoczywać w pokoju," Studia socjologiczne 199 (2010) no. 4, 305-312.

Korzec, C., "Kościół w doświadczeniu wewnętrznej sekularyzacji. Przypadek: Pismo święte," in: C. Korzec, R. Misiak (eds.), Nadzieje i zagrożenia sekularyzacji, Szczecin 2010, 41-57.

Luckmann, T., Niewidzialna religia. Problem religii w nowoczesnym społeczeństwie, L. Bluszcz (transl.), Kraków 2011.

Luhmann, N., Funkcja religii, D. Motak (transl.), Kraków 1998.

Mariański, J., Kościót katolicki w społeczeństwie obywatelskim. Refleksje socjologiczne, Lublin 1998.

Mariański, J., Sekularyzacja, desekularyzacja, nowa duchowość. Studium socjologiczne, Kraków 2013.

Mariański, J., Sekularyzacja i desekularyzacja w nowoczesnym świecie, Lublin 2006.

Mariański, J., "Sekularyzacja jako fakt społeczny," Studia Płockie 29 (2001), 185-200.

Mascall, E.L., Sekularyzacja chrześcijaństwa, T. Mieszkowski (transl.), Warszawa 1970.

Mazanka, P., "Refleksje o fillozoficznych źródłach sekularyzacji i sekularyzmu," Studia Nauk Teologicznych PAN 9 (2014), 55-83.

Napiórkowski, A., "Współczesny sekularyzm a teologia sekularyzacji," Studia Nauk Teologicznych PAN 9 (2014), 11-36.

Pertici, R., "Primacy of the Spiritual or Primacy of the Political?," http://magister.blogautore.espresso.repubblica.it (access 20.04.2020).

Possenti, V., Religia i życie publiczne. Chrześcijaństwo w dobie ponowożytnej, T. Żeleźnik (transl.), Warszawa 2005. 
Pszczołowski, T., Mała encyklopedia prakseologii i teorii organizacji, Wroclaw 1978.

Sarah, R., Diat, N., Wieczór się zbliża i dzień już się chyli, A. Kuryś (transl.), Warszawa 2019.

Sharpe, E., Understanding Religion, New York 1983.

Sokalska, E., "Biurokracja jako metoda funkcjonowania nowoczesnej administracji w ujęciu Maksa Webera," Studia Prawnoustrojowe 2 (2003), 115-124.

Suenens, L.J., Nowe Zestanie Ducha Świętego?, J. Fenrychowa (transl.), Poznań 1988.

Szahaj, A., Liberalizm, wspólnotowość, równość. Eseje z filozofii polityki, Toruń 2012.

Szahaj, A., "Wielość, względność, obojętność? O sekularyzacji i roli religii w debacie publicznej," in: C. Korzec, R. Misiak (eds.), Nadzieje i zagrożenia sekularyzacji, Szczecin 2010, 15-28.

Tischner, J., Myślenie wedtug wartości, Kraków 1982.

Weber, M., Racjonalność, władza, odczarowanie, M. Holona, A. Kopacki (transl.), Poznań 2004.

Weigel, G., Czym jest katolicyzm? Dziesięć kontrowersyjnych pytań, A. Gomola (transl.), Kraków 2003.

Weigel, G., Odwaga bycia katolikiem. Kryzys, reforma i przyszłość Kościoła, J. Franczak (transl.), Kraków 2004.

Woleński, J., Granice niewiary, Kraków 2004.

Wojciechowski, M., Teolog o ekonomii, Kraków 2015.

Zdybicka, Z.J., Człowiek i religia. Zarys filozofii religii, Lublin 1993.

Zdybicka, Z.J., "Religia i polityka," Człowiek w kulturze 3 (1994), 111-132.

Zieleniewski, J., Organizacja zespołów ludzkich: wstęp do teorii organizacji i kierowania, Warszawa 1976. 